\title{
Pengembangan Instrumen Penilaian Karakter PPK Aspek Kemandirian Pembelajaran Tematik Terpadu Siswa SD Kelas 4
}

\section{Nia Fuji Lestari ${ }^{*}$, Nyoto Harjono ${ }^{2}$}

${ }^{12}$ Program Studi Pendidikan Guru Sekolah Dasar, Universitas Kristen Satya Wacana, Salatiga, Indonesia

\begin{tabular}{l} 
A R T I C L E I N F O \\
\hline Article history: \\
Received 1 Januari 2021 \\
Received in revised form \\
30 Januari 2021 \\
Accepted 1 Maret 2021 \\
Available online 8 April \\
2021 \\
\hline
\end{tabular}

Kata Kunci: pengembangan, instrumen penilaian, karakter ppk

Keywords: development, assessment instrument, PPK character

\begin{abstract}
A B S T R A K
Kesulitan yang dihadapi guru saat ini adalah mengukur keberhasilan pembelajaran karakter. Tujuan dari penelitian ini adalah untuk mengembangkan instrumen penilaian karakter PPK aspek kemandirian menggunakan Skala Likert pada pembelajaran tematik terpadu siswa SD kelas 4 yang layak untuk digunakan. Penelitian ini merupakan penelitian Research \& Development dengan model pengembangan ADDIE. Pengumpulan data dilakukan melalui observasi, wawancara, dan angket. Jenis data yang digunakan merupakan data primer berupa data kuantitatif dan kualitatif. Instrumen yang digunakan berupa angket. Produk diujikan secara terbatas kepada 15 siswa kelas 4 yang berasal dari 3 sekolah berbeda. Data diolah menggunakan IBM SPSS 25 for Windows. Dari hasil uji terbatas diperoleh validitas dari 40 butir pernyataan yang diuji cobakan, 6 (15\%) butir pernyataan memiliki tingkat validitas sangat tinggi, 25 (62,5\%) katagori validitas tinggi, $6(15 \%)$ katagori validitas cukup, $3(7,5 \%)$ katagori validitas rendah, dan memiliki rata-rata rhitung sebesar $0,667 \geq 0,20$ maka instrumen dinyatakan valid. Reliabilitas instrumen memiliki alpha cronbach's $(\alpha)$ sebesar 0.965 dengan kriteria sangat reliabel. Berdasarkan hasil tersebut dapat disimpulkan bahwa instrumen penilaian karakter PPK aspek kemandirian pada pembelajaran tematik terpadu SD kelas 4 layak untuk digunakan. Implikasi penelitian ini yaitu instrumen yang dikembangkan dapat digunakan oleh guru untuk mengukur pembelajaran karakter.
\end{abstract}

\begin{abstract}
A B S T R A C T
The difficulty faced by teachers today is measuring the success of character learning. The purpose of this study was to develop a character assessment instrument for KDP in the aspects of independence using a Likert scale in integrated thematic learning for grade 4 elementary school students which is feasible to use. This research is a Research \& Development research with the ADDIE development model. Data collection was carried out through observation, interviews, and questionnaires. The type of data used is primary data in the form of quantitative and qualitative data. The instrument used was a questionnaire. The product was tested on a limited basis to 15 grade 4 students from 3 different schools. Data were processed using IBM SPSS 25 for Windows. From the limited test results, the validity of the 40 statement items tested, 6 (15\%) statement items had a very high validity level, 25 (62.5\%) high validity categories, $6(15 \%)$ sufficient validity categories, $3(7,5 \%)$ the category of low validity, and has an average rcount of $0.667 \geq 0.20$, the instrument is declared valid. The reliability of the instrument has an alpha Cronbach's (a) of 0.965 with very reliable criteria. Based on these results it can be concluded that the KDP character assessment instrument in the independent aspects of integrated thematic learning in SD grade 4 is feasible to use. This research implies that the instruments developed can be used by teachers to measure character learning.
\end{abstract}

\section{Pendahuluan}

Perkembangan zaman yang terus terjadi dan berjalan dengan pesat memunculkan berbagai paradigma baru yang memicu setiap aspek kehidupan untuk berkembang guna memenuhi tuntutan kehidupan yang ada, salah satunya adalah aspek pendidikan. Dunia pendidikan terus berkembang 
seiring dengan perubahan pada lingkungan sekolah yang didorong oleh kemajuan IPTEK, globalisasi, dan lingkungan (Wulandari, Sudatha, \& Simamora, 2020; Yusri, 2016). Hal ini dilakukan untuk meningkatkan mutu pendidikan khususnya di Indonesia. Pendidikan merupakan proses transformasi budaya dan nilai-nilai luhur kepribadian yang dilaksanakan secara sistematis dan terprogram (Tolchah, 2013). Melalui pendidikan manusia dilatih untuk mengembangkan potensi diri, kepribadian, kecerdasan dan keterampilan yang diperlukan bagi dirinya, masyarakat, dan negara (Sutrisno, 2016; Wulandari, Dantes, \& Antara, 2020). Tujuan dari penyelengaraan pendidikan hakikatnya adalah untuk membentuk sumber daya manusia yang memiliki karakter, watak serta kepribadian baik, cerdas, berakhlak mulia, terampil dan memiliki wawasan kebangsaan, sebagai bekal untuk menghadapi tantangan di masa depan. Untuk mencapai tujuan ini diperlukan adanya keseimbangan dalam pengembangan aspek pengetahuan (knowledge), keterampilan (skill), dan sikap (attitude) (Dahniar, 2019; Yuliawati, 2018). Kendati demikian jika kita lihat praktik nyatanya di lapangan, pendidikan yang berlangsung di Indonesia lebih menekankan pada pengetahuan/kecerdasan intelektual, padahal sikap atau nilai akhlak (moral) sangat besar perannya dalam menentukan tindakan sesorang. Banyak orang di negeri ini yang terjerat kasus bukan karena mereka memiliki intelektualitas rendah, tetapi karena moralitas yang buruk.

Saat ini, dapat kita jumpai berbagai fenomena sosial yang terjadi khususnya pada dunia pendidikan di Indonesia. Disekeliling kita dapat kita jumpai pelajar, lulusan pendidikan, maupun orang-orang dengan jabatan publik menunjukkan sikap yang kurang terpuji seperti berperilaku kasar, kurang sopan, suka berbohong, tidak menghormati orang yang lebih tua atau suka menang sendiri, tidak bertanggung jawab, tidak mau mengakui kesalahan, dan sebagainya. Adanya fenomena tersebut mendorong pemerintah Indonesia untuk menata kembali seluruh aspek pendidikan yang ada di Indonesia. Salah satunya melalui paradigma baru dunia pendidikan yaitu pembaruan kurikulum (Mulyadin, 2016; Sofyan, 2016). Pembaruan kurikulum di Indonesia yang sampai saat ini masih digunakan dan terus disempurnakan adalah Kurikulum 2013. Kurikulum 2013 menjanjikan lahirnya generasi penerus bangsa yang produktif, kreatif, inovatif, dan berkarakter (Lismawati, 2015; Wahyudin, 2018). Dalam pengimplementasian kurikulum 2013 terdapat beberapa agenda salah satunya yaitu program Penguatan Pendidikan Karakter (PPK). Di dalam Rencana Pembangunan Jangka Panjang Nasional (RPJPN) tahun 2005-2025 pembangunan karakter merupakan salah satu program prioritas pembangunan nasional yang dicanangkan oleh Pemerintah (Kamal, 2007; Manasikana \& Anggraeni, 2018). Sejalan dengan hal ini pemerintah menerbitkan Perpres No. 87 Tahun 2017 tentang Penguatan Pendidikan Karakter (PPK). Pembelajaran di sekolah dasar menggunakan pembelajaran tematik terpadu. Di dalam Kurikulum 2013 ranah sikap (afektif) terdiri dari dua aspek yaitu sikap sosial dan sikap spiritual. Kompetensi Dasar yang digunakan dalam sikap spiritual adalah KD-1 sedangkan aspek sikap sosial pada KD-2.

Permasalahan yang terjadi saat ini adalah masih jarang ditemukan instrumen penilaian pendidikan karakter yang memadahi, valid, dan reliabel yang dapat digunakan secara tepat. Hal ini sejalan dengan penelitian yang dilakukan oleh Zuliani, Florentinus, \& Ridlo (2017) yang menyatakan bahwa guru masih kesulitan untuk menyusun instrumen penilaian pendidikan karakter. Penelitian yang dilakukan oleh Gaol, Khumaedi, \& Masrukan (2017) juga menyatakan bahwa instrumen penilaian karakter khususnya percaya diri belum tersedia di lapangan yang menyebabkan penilaian karakter belum dapat dilakukan secara maksimal. Permasalahan ini juga terjadi di salah satu sekolah dasar. Berdasarkan hasil wawancara kepada Kepala sekolah dan Guru SD Negeri Pringapus 02, SD Negeri Pringapus 03, dan SD Negeri Sambirejo 02 didapatkan hasil bahwa pelaksanaan penilaian karakter telah dilakukan meskipun belum maksimal. Dalam pelaksanaannya guru menggunakan instrumen penilaian yang ada di dalam buku guru ataupun mengembangkan sendiri. Guru cenderung mengikuti instrumen penilaian yang sudah ada di buku guru dan menggunakannya untuk menilai karakter siswa meskipun belum mencakup seluruh aspek sikap yang ada dalam karakter PPK. Guru melakukan penilaian karakter tanpa mengembangkan instrumen secara mandiri, akan tetapi hanya menggunakan instrumen penilaian sikap yang ada di dalam buku guru. Beberapa guru mengembangkan instrmen penilaian mengacu pada penilaian sikap yang ada di dalam buku guru dan cenderung melakukan penilaian karakter menggunakan tabel pengamatan sikap bukan instrumen khusus untuk menilai karakter. Pada beberapa kegiatan pembelajaran guru dituntut untuk mengembangkan instrumen penilaian karakter secara mandiri dikarenakan pada buku guru tidak terdapat penilaian sikap. Akan tetapi pada kenyataannya guru cenderung memilih untuk melaksanakan penilaian sesuai apa yang ada 
di buku guru, tanpa menambahkan instrumen penilaian sikap. Hal seperti ini terjadi dalam pembelajaran tematik kelas 4 tema 7 Indahnya Keragaman di Negeriku subtema 1 Keragaman Suku Bangsa dan Agama pembelajaran 3. Pada pembelajaran ini terdapat muatan pembelajaran PPKn yang memuat KI-1 dan KI-2 (ranah sikap/afektif) akan tetapi pada buku guru tidak terdapat instrumen penilaian sikap, hanya terdapat instrumen penilaian pengetahuan dan keterampilan untuk menilai KI3 dan KI-4. Sehingga guru dituntut untuk mengembangkan instrumen penilaian karakter secara mandiri.

Pendidikan karakter sebagai usaha sadar dan terencana dalam menginternalisasikan nilai-nilai karakter sehingga karakter tersebut dapat dimengerti, dihayati dan dilaksanakan dalam kehidupan sehari-hari oleh peserta didik (Luthviyani, Setianingsih, \& Handayani, 2019; Nida, Parmiti, \& Sukmana, 2020). Pendidikan karakter memang sudah dijalankan dan diimplementasikan ke sekolah-sekolah, namun di dalam pengimplementasiannya masih diperlukan perangkat pembelajaran yang mendukung dan memadahi meliputi silabus, rencana pembelajaran, pelaksanaan pembelajaran yang inovatif, media pembelajaran, dan instrumen penilaian. Pada hakikatnya, pendidikan karakter bertujuan untuk menanamkan nilai dan menumbuhkan sikap dan perilaku yang baik untuk membentuk karakter siswa (Harahap, 2019). Implementasi pendidikan karakter adalah aplikasi di sekolah dan di luar sekolah dengan partisipasi seluruh warga sekolah dan dukungan dari keluarga siswa (Pratiwi, 2020; Rahmadani, 2020). Pada dasarnya, tujuan penilaian karakter bukan untuk memberikan nilai karakter siswa, tetapi untuk mendapatkan gambar informasi perkembangan karakter siswa, sehingga dapat dilihat perkembangan apa yang terjadi pada karakter siswa, dan menggunakannya sebagai patokan untuk upaya mengembangkan atau memperkuat karakter siswa (Cahyaningrum, Sudaryanti, \& Purwanto, 2017). Oleh karena itu evaluasi secara khusus pancapaian nilai-nilai karakter juga perlu dilaksanakan secara maksimal. Karakter seseorang dapat terlihat dari sikap atau perilakunya.

Sikap seseorang tidak dapat diamati secara langsung, melainkan harus ditafsirkan terlebih dahulu dari tingkah laku yang tampak baik verbal maupun nonverbal. Dalam mengukur sikap ada empat pendekatan yang dapat digunakan, yaitu: (1) menggunakan laporan diri sendiri (self-report), (2) laporan orang lain, (3) prosedur sosiometri, dan (4) pencatatan dokumen (Nita \& Zaini, 2017; Siregar, 2016). Dari keempat pendekatan tersebut dikembangkan teknik-teknik yang dapat digunakan untuk mengukur sikap, seperti: wawancara langsung, laporan tertulis, kuesioner, pengumpulan pendapat (polls), observasi, teknik pilihan sosial, skala sikap, dll. Salah satu model skala sikap yang dapat digunakan adalah Skala Likert. Skala Likert pertama kali dikembangkan oleh Rensis Likert pada tahun 1923 dalam mengukur sikap masyarakat Skala ini menggunakan ukuran ordinal sehingga dapat membuat rangking walaupun tidak diketahui berapa kali responden yang satu lebih baik atau lebih buruk dari responden lainnya (Setiawati, Mardapi, \& Azwar, 2013; Suwandi, Edi, 2019). Pada skala Likert ada tiga pilihan skala, yaitu skala tiga, skala empat, dan skala lima, namun biasanya yang sering digunakan adalah skala lima (Adib, 2017). Dalam penggunaan Skala Likert jawaban dari setiap item instrumen memiliki gradasi/tingkatan yang berbeda dari sangat positif sampai sangat negative, yang disajikan dalam bentuk kata antara lain: sangat setuju (SS), setuju (ST), ragu-ragu (R), tidak setuju (TS), dan sangat tidak setuju (STS) (Maryuliana, 2016; Nugroho et al., 2019). Skala likert digunakan untuk mengembangkan instrumen. Instrumen merupakan suatu alat yang dipergunakan untuk mengukur suatu objek ukur atau mengumpulkan data dari suatu variable (Maulida, Dibia, \& Astawan, 2020; Sappaile, 2007). Suatu instrumen dikatakan baik bila memenuhi tiga syarat, yaitu valid, realibel, dan visibilitas.

Penelitian ini dilakukan dengan tujuan untuk menghasilkan produk instrumen penilaian karakter PPK aspek kemandirian menggunakan skala Likert untuk siswa SD kelas 4 yang valid dan reliabel sehingga layak untuk diguanakan. Diharapkan produk ini nantinya dapat digunakan sebagai referensi guru dalam melakukan penilaian karakter PPK khususnya aspek kemandirian.

\section{Metode}

Penelitian ini adalah jenis penelitian pengembangan atau R\&D (Research \& Development). Dalam pengembangan ini produk baru yang dikembangkan berupa instrumen penilaian karakter dengan menggunakan skala likert. Penelitian pengembangan ini menggunakan siklus penelitian pengembangan menurut Sukmadinata (2013), yaitu melalui tiga tahap sebagai berikut: (1) Studi pendahuluan; (2) Desain dan pengembangan produk; (3) Pengujian produk (Simarmata, Wardani, \& 
Prasetyo, 2019). Desain dan pengembangan instrumen penilaian karakter PPK aspek kemandirian dilakukan sesuai dengan model pengembangan ADDIE yang dikembangkan oleh Molenda dan Raiser (2003). Adapun tahap pengembanganya menurut Branch (Nababan, 2020) adalah sebagai berikut: (1) Analysis, (2) Design, (3) Development, (4) Implementation, dan (5) Evaluation.

Jenis data yang digunakan dalam penelitian ini merupakan data primer baik berupa data kuantitatif maupun data kualitatif mengenai informasi penelitian. Data ini diperlukan untuk mengetahui seberapa tingkat kelemahan atau kekurangan dari instrumen penilaian yang telah dibuat sebagai dasar penyusunan pengembangan instrumen penilaian karakter dengan skala Likert. Teknik pengumpulan data yang digunakan dalam penelitian ini adalah teknik observasi, wawancara, dan angket (produk instrumen penilaian karakter). Instrumen pengumpulan data yang digunakan adalah instrumen butir pernyataan berupa angket yang berisikan 40 soal berbentuk pernyataan yang disajikan dalam skala likert, yang nantinya akan diolah menggunakan IBM SPSS 25 for windows. Analisis data menggunakan teknik analisis data kualitatif berupa persentase yang bersumber dari hasil uji validitas instrumen penilaian yang nantinya dianalisis dan disajikan secara deskriptif dan kategoris untuk mengetahui gambaran dari kelayakan instrumen penilaian yang telah dibuat

\section{Hasil dan Pembahasan}

Penelitian ini menghasilkan sebuah produk instrumen peneliaian karakter PPK aspek kemandirian pembelajaran tematik terpadu siswa SD kelas 4. Tahap studi pendahuluan dilakukan dengan melakukan observasi atau survey di SD Negeri Pringapus 02, SD Neger Pringapus 03, dan SD Negeri Sambirejo 02 terkait dengan pelaksanaan penilaian karakter PPK aspek kemandirian. Hasil dari pengembangan instrumen penilaian karakter PPK aspek kemandirian menggunakan model pengembangan ADDIE adalah sebagai berikut.

Tahap pertama yaitu analisis. Pada kegiatan analisis kinerja dilakukan wawancara terkait instrumen penilaian karakter PPK aspek kemandirian di 3 sekolah yaitu SD Negeri Pringapus 02, SD Neger Pringapus 03, dan SD Negeri Sambirejo 02. Hasil wawancara menyatakan bahwa di beberapa SD belum terdapat instrumen penilaian karakter, guru hanya menggunakan penilaian yang ada di buku guru, sedangkan di beberapa SD lainnya sudah ada instrumen penilaian karaker akan tetapi belum diketahui validitas dan reliabilitasnya. Dalam menilai karakter, guru cenderung menggunakan penilaian yang ada di buku guru tanpa mengembangkan kembali dan menyesuaikan dengan kebutuhan pembelajaran. Untuk mengatasi permasalahan tersebut maka peneliti mengembangkan instrumen penilaian karakter kelas 4 SD. Tahap analisis yang kedua yaitu analisis kebutuhan siswa. Berdasarkan hasil dari analisis kebutuhan melalui pengamatan dan wawancara kepada guru dan orang tua siswa, diketahui bahwa yang diperlukan siswa adalah mengetahui mengetahui kemandiriannya dalam belajar karena kondisi covid-19. Untuk mengetahui kondisi sebenarnya atas kemandirian siswa diperlukan alat ukur yakni instrumen penilaian karakter PPK aspek kemandirian, maka peneliti perlu menganalisis kurikulum yang digunakan oleh sekolah, mengkaji silabus, Kompetensi Inti dan Kompetensi Dasar kelas 4 SD untuk mengetahui pembelajaran apa yang akan berlangsung saat akan dilaksanakan penelitian. Dari hasil analisis inilah peneliti mengembangkan instrumen penilaian karakter peserta didik kelas 4 pada pembelajaran Tema 7 "Indahnya Keragaman di Negeriku” Subtema 1 "Keragaman Suku Bangsa dan Agama di Negeriku” Pembelajaran 3.

Tahap Kedua yaitu desain atau perencanaan. Dari proses pengkajian silabus kelas 4 semester 2 didapatkan bahwa pada Tema 7 "Indahnya Keragaman di Negeriku" Subtema 1 "Keragaman Suku Bangsa dan Agama di Negeriku" Pembelajaran 3 hanya terdapat penilaian ranah pengetahuan dan keterampilan, sedangkan sikap tidak ada. Oleh karena itu, peneliti memutuskan untuk melakukan pengembangan instrumen penilaian karakter PPK aspek kemandirian pada pembelajaran ini. Dalam penelitian ini sikap kemandirian dinilai melalui nilai-nilai karakter mandiri yang ada di dalam buku model penilaian karakter (Tim Pusat Penilaian Karakter, 2019). Nilai-nilai ini dikembangkan menjadi indikator yang nantinya akan digunakan untuk menyusun instrumen. Sejalan dengan hal itu, diperhatikan pula Kompetensi Inti (KI-2) sikap sosial. Kompetensi Dasar yang digunakan dalam penelitian ini adalah KD 2.4 yang dapat digunakan untuk menilai karakter. Setelah indikator ditentukan, langkah selanjutnya yaitu menyusun desain pembelajaran dalam RPP tematik. Dalam penyusunan RPP tematik ini dilakukan dengan merancang langkah-langkah pembelajaran, menentukan materi pembelajaran, pendekatan, model, dan menyusun evaluasi. Evaluasi dirancang 
dengan menyusun kisi-kisi instrumen penilaian karakter PPK aspek kemandirian dengan menggunakan skala Likert. Kisi-kisi instrumen penilaian karakter PPK aspek kemandirian pembelajaran tematik kelas IV tema 7 Indahnya Keragaman di Negeriku subtema 1 Keragaman Suku Bangsa dan Agama di Negeriku semester 2 disajikan melalui tabel 3.3 sebagai berikut:

Tabel 4. Kisi-kisi Instrumen Penilaian Karakter PPK Pembelajaran Tematik Kelas 4 Tema 7

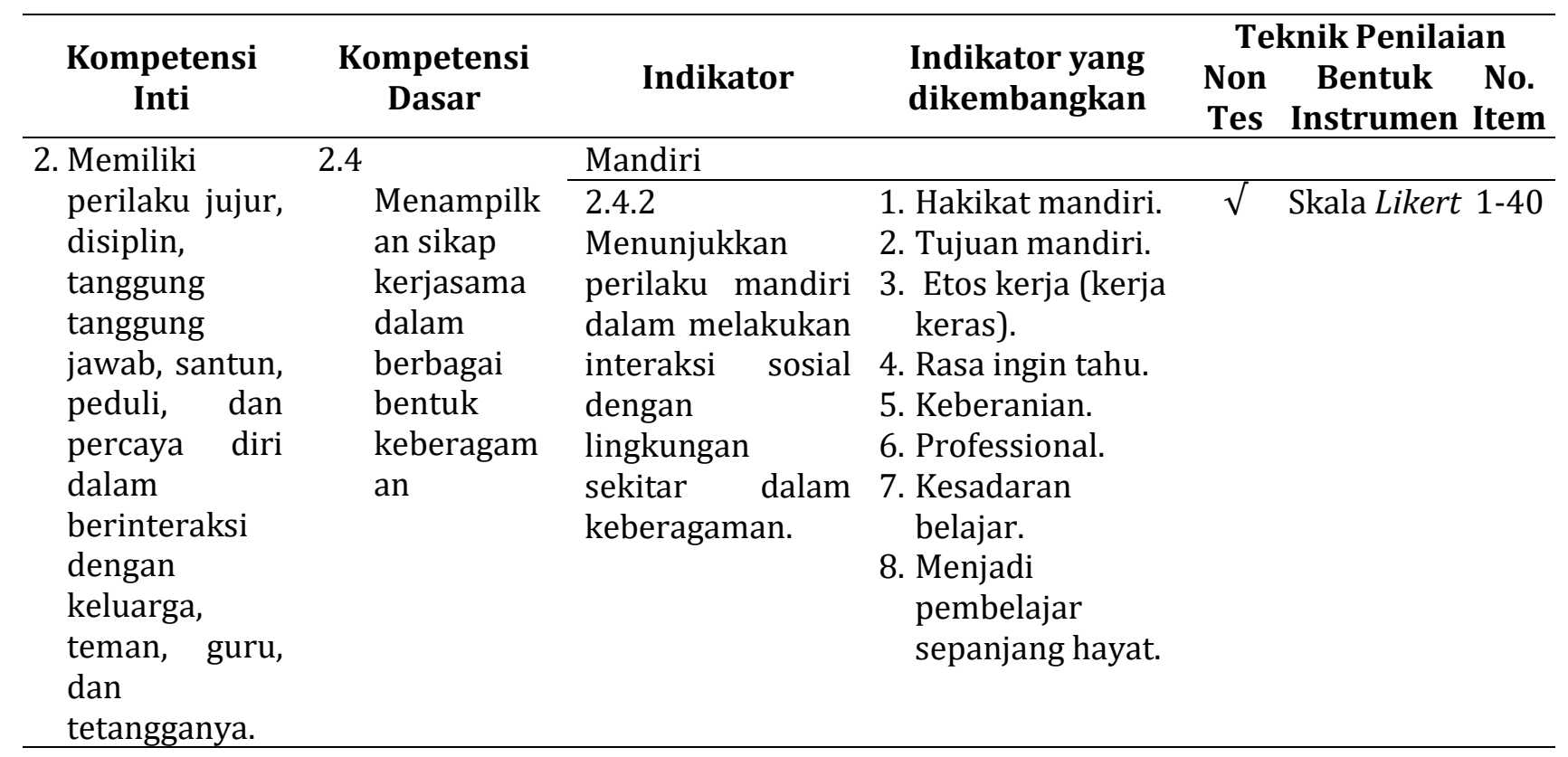

Tahap Ketiga yaitu pengembangan (Development). Pada tahap ini melakukan penyusunan butir-butir pernyataan berdasarkan kisi-kisi yang telah dibuat. Pernyataan dibuat berdasarkan 3 aspek sikap yaitu kognisi, afeksi, dan konasi yang terdiri dari pernyataan favorabel dan unfavorabel. Pernyataan yang telah disusun disajikan dalam tabel 5 , berikut ini.

Tabel 5. Instrumen Penilaian Karakter PPK Aspek Kemandirian Peserta Didik

\begin{tabular}{ll}
\hline No. & \multicolumn{1}{c}{ Pernyataan } \\
\hline 1. Mandiri hakikatnya adalah tidak bergantung kepada orang lain dalam menyelesaikan setiap \\
tugas yang dimiliki. \\
2. Mandiri menyebabkan saya tidak bisa meminta bantuan kepada orang lain dan kesulitan \\
menyelesaikan setiap tugas yang saya miliki. \\
3. Mandiri hakikatnya membuat saya terbiasa mempergunakan tenaga, pikiran, waktu yang saya \\
miliki untuk merealisasikan harapan, mimpi, dan cita-cita. \\
4. Mandiri akan menghambat saya karena harus mempergunakan tenaga, pikiran, waktu untuk \\
merealisasikan harapan, mimpi, dan cita-cita tanpa bantuan orang lain. \\
5andiri bertujuan untuk membentuk watak, akhlak, budi pekerti, dan mental individu, agar \\
6. Mandiri tidak dapat membentuk watak, akhlak, budi pekerti, dan mental individu, agar \\
7. Saya mendukung perilaku mandiri karena mempercepat selesainya tugas-tugas yang saya \\
8. Saya kurang mendukung perilaku mandiri karena membuat saya tidak bisa meminta tolong \\
kepada orang lain ketika kesulitan mengerjakan tugas. \\
9. Saya mendukung adanya pemberian tugas karena membuat saya merasa semangat untuk \\
10. Saya kurang mendukung adanya pemberian tugas karena membuat saya merasa terbebani. \\
11. Ketika mendapatkan tugas, saya akan berusaha menyelesaikannya sebaik mungkin. \\
12. Ketika mendapatkan tugas, saya hanya mengerjakan soal yang saya anggap mudah.
\end{tabular}




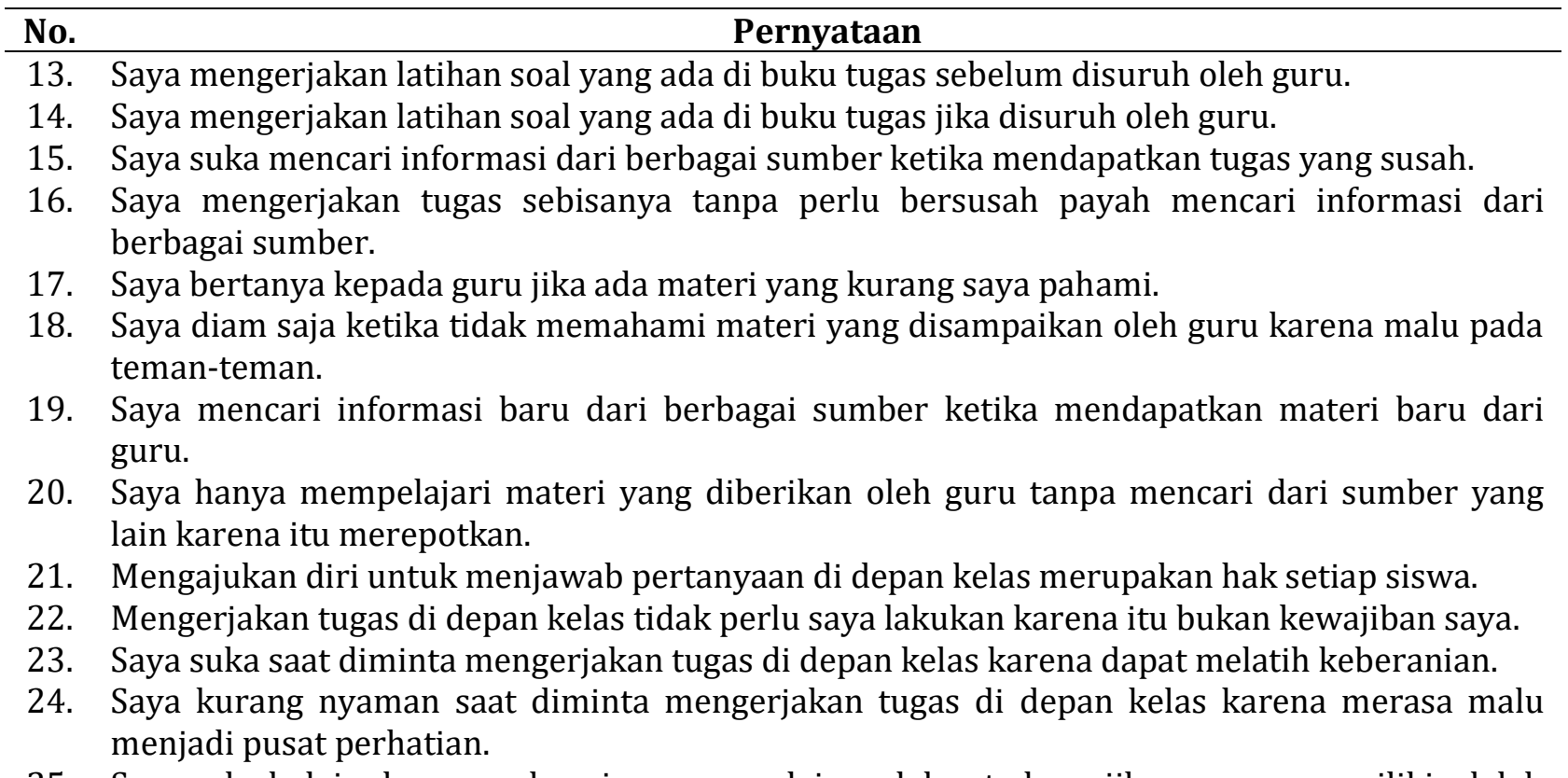

25. Saya suka belajar karena sebagai seorang pelajar salah satu kewajiban yang saya miliki adalah belajar.

26. Saya tidak suka belajar karena itu bukanlah kewajiban saya sebagai seorang pelajar

27. Saya akan menyelesaikan tugas sekolah sebelum melakukan kegiatan lainnya.

28. Saya akan pergi bermain meskipun tugas sekolah saya belum selesai.

29. Memiliki jadwal belajar yang teratur dapat meningkatkan kualitas belajar.

30. Memiliki jadwal belajar teratur tidak memberikan dampak pada kualitas belajar.

31. Saya mendukung adanya jadwal belajar rutin karena itu dapat membuat saya rajin mengerjakan tugas.

32. Saya kurang mendukung adanya jadwal belajar rutin karena itu dapat mengganggu waktu bersantai saya.

33. Saya akan belajar meskipun tidak ada yang mengawasi.

34. Saya akan belajar jika diawasi oleh orang lain.

35. Saya mempelajari kembali materi yang telah disampaikan oleh guru agar lebih paham.

36. Saya tidak mempelajari kembali materi yang telah disampaikan oleh guru meskipun saya belum paham.

37. Mempelajari kembali materi yang sudah diajarkan tidak perlu dilakukan, karena tidak ada informasi baru yang akan saya dapatkan.

38. Materi harus dipelajari dengan baik, karena akan selalu ada informasi baru yang mengubah pengetahuan saya.

39. Saya selalu menjaga semangat belajar meskipun hasil yang saya dapatkan belum maksimal.

40. Saya kurang semangat dalam belajar ketika hasil yang saya dapatkan tidak sesuai dengan keinginan saya.

Instrumen penilaian karakter PPK yang telah disusun kemudian divalidasi oleh ahli bahasa, ahli penilaian, dan ahli materi. Dari hasil uji validasi ahli penilaian diperoleh skor 45 dari total skor 56 dengan persentase sebesar $80,3 \%$ yang berarti termasuk dalam kategori tinggi, uji validasi ahli bahasa diperoleh skor 41 dari total skor 48 dengan persentase sebesar 85,4\% yang berarti termasuk dalam kategori sangat tinggi, uji validasi ahli materi diperoleh skor 32 dari total skor 36 dengan presentase sebesar $88,8 \%$ yang berarti termasuk dalam kategori sangat tinggi.

Tahap keempat yaitu implementasi. Pada tahap ini Produk yang telah divalidasi oleh ahli dan selesai direvisi kemudiaan diimplementasikan secara terbatas. Uji coba terbatas dilakukan dengan memberikan angket instrumen penilaian karakter kepada 15 siswa dari SD Negeri Pringapus 02, SD Neger Pringapus 03, dan SD Negeri Sambirejo 02. Dari uji coba terbatas didapatkan bahwa dari 40 butir pernyataan yang diuji cobakan, $6(15 \%)$ butir pernyataan memiliki tingkat validitas sangat tinggi, 25 (62,5\%) butir pernyataan memiliki tingkat validitas tinggi, 6 (15\%) butir pernyataan memiliki tingkat validitas cukup, $3(7,5 \%)$ butir pernyataan memiliki tingkat validitas rendah. 
Tabel 6. Distribusi Validitas Instrumen Uji Coba Produk Terbatas

\begin{tabular}{clcc}
\hline \multirow{2}{*}{ Rentang Indeks } & \multirow{2}{*}{ Kategori } & \multicolumn{2}{c}{ Ujicoba Produk Terbatas } \\
\cline { 3 - 4 } & & Frekuensi butir soal & $\mathbf{\%}$ \\
\hline $0,81-1,00$ & Sangat tinggi & 6 & 15 \\
$0,61-0,80$ & Tinggi & 25 & 62,5 \\
$0,41-0,60$ & Cukup & 6 & 15 \\
$0,21-0,40$ & Rendah & 3 & 7,5 \\
$0,00-0,20$ & Sangat rendah & 0 & 0 \\
\hline & Jumlah & $\mathbf{4 0}$ & $\mathbf{1 0 0}$ \\
\hline
\end{tabular}

Dari hasil uji terbatas didapatkan rhitung terendah sebesar 0,296 yang berada pada rentang 0,21-0,40 dengan kategori validitas rendah. Sedangkan rhitung tertinggi sebesar 0,932 yang berada pada rentang 0,81-1,00 dengan kategori validitas sangat tinggi. Hasil penelitian menunjukkan ratarata rhitung sebesar $0,667 \geq 0,20$ maka instrumen dinyatakan valid. Sedangkan reliabilitas pada uji terbatas diperoleh $\alpha$ sebesar 0.965 dengan kriteria sangat reliabel. Hasil uji reliabilitas pada uji coba terbatas dapat dilihat pada tabel berikut.

Tabel 7. Indeks Reliabilitas

\begin{tabular}{ccc}
\hline Ujicoba Produk & $\boldsymbol{\alpha}$ & Kriteria \\
\hline Uji Coba Terbatas & 0,965 & Sangat Reliabel \\
\hline
\end{tabular}

Uji coba luas tidak dilaksanakan karena adanya pandemi covid-19 sehingga tidak memungkinkan untuk untuk melakukan penelitian secara luas.

Tahap terakhir yaitu tahap evaluasi. Pada tahap validasi instrumen penilaian karakter PPK aspek kemandirian mendapatkan evaluasi pada pernyataan kognisi nomor 8 dan pernyataan afeksi nomor 2. Peneliti melakukan revisi sebelum melakukan uji terbatas. Dari hasil analisis uji terbatas diketahui terdapat 4 pernyataan yang belum valid, yaitu pernyataan nomor 13, 15, 21, 31 yang kemudian diperbaiki. Pengujian produk dilakukan melalui uji terbatas sebanyak satu kali dengan jumlah responden 15 siswa yang berasal dari SD Negeri Pringapus 02, SD Negeri Pringapus 03, dan SD Negeri Sambirejo 02.

Berdasarkan hasil uji terbatas instrumen penilaian karakter PPK aspek kemandirian, dari 40 butir pernyataan yang telah diujicoba, diperoleh $r_{\text {hitung }}$ terendah sebesar 0,296 dengan kategori validitas rendah dan $r_{\text {hitung }}$ tertinggi sebesar 0,932 dengan kategori validitas sangat tinggi. Hasil penelitian menunjukkan rata-rata $r_{\text {hitung }}$ sebesar $0,667 \geq 0,20$ maka instrumen dinyatakan valid. Sedangkan reliabilitas pada uji terbatas diperoleh skor alpha cronbach's $(\alpha)$ sebesar 0.965 dengan kriteria sangat reliabel. Dapat disimpulkan bahwa instrument yang dikembangkan layak untuk digunakan. Hal tersebut disebabkan oleh beberapa faktor yaitu sebagai berikut.

Pertama, instrumen pengembangan karakter yang dikembangkan telah sesuai dan memenuhi kriteria kelayakan. Nilai karakter mandiri dalam PPK diwujudkan dalam sikap dan perilaku tidak bergantung pada orang lain dan mempergunakan segala tenaga, pikiran, waktu untuk merealisaiskan harapan, mimpi dan cita-cita (Barus, 2015; Yudhawati, 2020). Kemandirian mengandung beberapa pengertian yaitu: (1) suatu kondisi dimana sesorang memiliki hasrat untuk bersaing dengan orang lain untuk maju demi kebaikan diri sendiri; (2) mampu mengambil keputusan dan inisiatif untuk mengatasi masalah yang dihadapi; (3) memiliki kepercayaan diri dalam melaksanakan tugas-tugasnya; dan (4) bertanggung jawab atas setiap tindakan yang dilakukannya (Sobri, Nursaptini, \& Novitasari, 2020; Suhendri, 2011). Sub-nilai mandiri yang dapat ditemukan antara lain adalah etos kerja (kerja keras), tangguh tahan banting, daya juang, profesional, kreatif, keberanian dan menjadi pembelajar sepanjang hayat. Sehingga dapat disimpulkan indikator kemandirian yang digunakan dalam mengembangkan instrumen penilaian karakter kemandirian ini ada delapan, yaitu: hakikat mandiri, tujuan mandiri, etos kerja (kerja keras), rasa ingin tahu, keberania, profesional, kesadaran belajar, dan menjadi pembelajar sepanjang hayat. 
Kedua, instrumen pengembangan karakter yang dikembangkan layak digunakan karena kepraktisan instrumen. Kepraktisan instrument dilihat dari haris menyebarkan angket kepada guru. Berdasarkan hasil penyebaran angket didapatkan bahwa instrument yang dikembangkan sangat bermanfaat bagi guru. Hal ini sesuai dengan pendapat Wijayanti, Sukestiyarno, \& Masrukhi (2015) yang menyatakan bahwa pengembangan instrument merupakan upaya dalam mengembangan instrument berdasarkan analisis kebutuhan dan diuji kefektifannya sehingga menghasilkan instrument yang berfungsi dan menfaat. Instrumen merupakan suatu alat yang dipergunakan untuk mengukur suatu objek ukur atau mengumpulkan data dari suatu variable (Maulida et al., 2020; Sappaile, 2007). Suatu instrumen dikatakan baik bila memenuhi tiga syarat, yaitu valid, realibel, dan visibilitas.

Penelitian yang dilakukan oleh Sutijan, Makhfud, Lestari, \& Chumdari (2015) hasil penelitian menunjukkan $r_{\text {hitung }}$ paling rendah sebesar $0,398 \geq 0,20$ maka instrumen dinyatakan valid. Sejalan dengan Sutijan, penelitian yang sama juga dilakukan Kartono (2013) hasil penelitian menunjukkan $r_{\text {hitung }}$ sebesar $0,312 \geq 0,20$ dan skor alpha cronbach's $(\alpha)$ sebesar 0,931 maka instrumen penilaian dinyatakan valid dan reliabel. Instrumen penilaian karakter yang di hasilkan telah memenuhi kriteria. Produk instrumen penilaian karakter PPK aspek kemandirian memiliki butir pernyataan yang valid sehingga dapat digunakan untuk mengukur kemandirian siswa. Berdasarkan hasil uji terbatas terhadap 15 siswa yang berasal dari 3 sekolah berbeda, didapatkan hasil bahwa pernyataan dalam instrumen penilaian karakter PPK aspek kemandirian memiliki validitas dan reliabilitas yang tinggi sehingga layak digunakan.

Berdasarkan survei lapang diketahui bahwa instrumen penilaian karakter PPK aspek kemandirian pada pembelajaran tematik terpadu kelas 4 belum dikembangkan, sehingga kelebihan dari penelitian ini adalah dapat menghasilkan instrumen penilaian karakter PPK aspek kemandirian yang valid dan reliabel, sehingga dapat membantu guru untuk menilai kemandirian siswa. Implikasi penelitian ini yaitu guru dapat menggunakan instrumen yang dikembangkan untuk mengukur pembelajaran karakter, dan menjadikan instrument ini sebagai pedoman untuk membuat instrument penilaian karakter lainya.

\section{Simpulan}

Berdasarkan hasil penelitian dan pembahasan yang telah dilakukan, dapat disimpulkan bahwa instrumen penilaian karakter PPK aspek kemandirian layak untuk digunakan, hal ini dapat dilihat hasil uji coba terbatas didapatkan bahwa dari 40 butir pernyataan yang diuji cobakan diperoleh $\mathrm{r}_{\text {hitung }}$ terendah sebesar 0,296 dengan kategori validitas rendah dan $r_{\text {hitung }}$ tertinggi sebesar 0,932 dengan kategori validitas sangat tinggi, dan rata-rata $r_{\text {hitung }}$ sebesar $0,667 \geq 0,20$ maka instrumen dinyatakan valid. Sedangkan reliabilitas instrumen memiliki alpha cronbach's $(\alpha)$ sebesar 0.965 dengan kriteria sangat reliabel.

\section{Daftar Pustaka}

Adib, H. S. (2017). Teknik Pengembangan Instrumen Penelitian Ilmiah Di Perguruan Tinggi Keagamaan Islam. Prosiding Seminar Nasional Dan Internasional, 1(1), 139-157. Retrieved from https://jurnal.unimus.ac.id/index.php/psn12012010/article/view/3054

Barus, G. (2015). Menakar Hasil Pendidikan Karakter Terintegrasi Di SMP. Cakrawala Pendidikan, 34(2). https://doi.org/https://doi.org/10.21831/cp.v2i2.4827

Cahyaningrum, E. S., Sudaryanti, S., \& Purwanto, N. A. (2017). Pengembangan Nilai-Nilai Karakter Anak Usia Dini Melalui Pembiasaan Dan Keteladanan. Jurnal Pendidikan Anak, 6(2), 203-213. https://doi.org/10.21831/jpa.v6i2.17707

Dahniar, A. (2019). Memahami Pembentukan Sikap (Attitude) Dalam Pendidikan Dan Pelatihan. Tatar Pasundan : Jurnal Diklat Keagamaan, 13(2), 202-206. https://doi.org/10.38075/tp.v13i2.27

Gaol, P. L., Khumaedi, M., \& Masrukan, M. (2017). Pengembangan Instrumen Penilaian Karakter Percaya Diri pada Mata Pelajaran Matematika Sekolah Menengah Pertama. Journal of Research and Educational Research Evaluation, 6(1). https://doi.org/https://doi.org/10.15294/jrer.v6i1.16209 
Harahap, A. C. P. (2019). Character Building Pendidikan Karakter. Jurnal Pendidikan Dan Konseling, 9(1), 1-11. $\quad$ https://doi.org/http://jurnal.uinsu.ac.id/index.php/alirsyad/article/view/6732/0

Kamal, M. (2007). Restrukturisasi Pendidikan Menuju Bangsa Berkarakter. STIT Pemalang, (17), 3544.

Kartono, C. S. (2013). Pengembangan Model Instrumen Penilaian Pendidikan Karakter Dalam Pembelajaran Di Sekolah Dasar. Jurnal Pendidikan Dasar, 1(2). Retrieved from https://jurnal.fkip.uns.ac.id/index.php/diksar/article/view/5423

Lismawati. (2015). Evaluasi implementasi kurikulum tingkat satuan pendidikan (ktsp) 2013 pada pelajaran al-islam di sd muhammadiyah 5 jakarta. Pendidikan Islam, 7(2), 53-66. Retrieved from https://journal.uhamka.ac.id/index.php/jpi/article/view/178

Luthviyani, Setianingsih, \& Handayani. (2019). Analisis Pelaksanaan Ekstrakurikuler Pramuka Terhadap Nilai-nilai Karakter Siswa di SD Negeri Pamongan. Jurnal Ilmiah Pendidikan Guru Sekolah Dasar, 12(2), 113-122. https://doi.org/10.33369/pgsd.12.2.113-122

Manasikana, A., \& Anggraeni, C. W. (2018). Pendidikan karakter dan mutu pendidikan indonesia. Prosiding Seminar Nasional Pendidikan 2018, Universitas Muhammadiyah Surakarta, 102-110.

Maryuliana, dkk. (2016). Sistem Informasi Angket Pengukuran Skala Kebutuhan Materi Pembelajaran Tambahan Sebagai Pendukung Pengambilan Keputusan Di Sekolah Menengah Atas Menggunakan Skala Likert. Jurnal Transistor Elektro Dan Informatika, 1(2), 1-12. https://doi.org/http://dx.doi.org/10.30659/ei.1.1.1-12

Maulida, I., Dibia, I. K., \& Astawan, I. G. (2020). The Development of Social Attitude Assessment Instrument and Social Studies Learning Outcomes Grade IV on Theme of Indahnya Keragaman di Negeriku. Indonesian Journal Of Educational Research and Review, 3(1), 12. https://doi.org/10.23887/ijerr.v3i2.25823

Mulyadin. (2016). Implementasi Kebijakan Pembelajaran Tematik Terpadu Kurikulum 2013 Di SDN Kauman 1 Malang Dan Sd Muhammadiyah 1 Malang. Jurnal Pendidikan Edutama, 3(2), 31 - 48. https://doi.org/http://dx.doi.org/10.30734/jpe.v3i2.35

Nababan, N. (2020). Pengembangan Media Pembelajaran Berbasis Geogebra Dengan Model Pengembangan Addie Di Kelas Xi Sman 3 Medan ( Development of Geogebra-Based Learning Media With Addie Development Models in Class Xi Sman 3 Medan ). Inspiratif: Jurnal Pendidikan Matematika, 6(1), 37-50. https://doi.org/https://doi.org/10.24114/jpmi.v6i1.19657

Nida, Parmiti, \& Sukmana. (2020). Pengembangan Media Kartu Bergambar Berorientasi Pendidikan Karakter Pada Mata Pelajaran Bahasa Bali. Jurnal EDUTECH Universitas Pendidikan Ganesha., 8(1), 16-31. Retrieved from https://ejournal.undiksha.ac.id/index.php/JEU/article/view/25393/15846

Nita, R. W., \& Zaini, A. (2017). Analisis Aplikasi Sosiometri Untuk Pengungkapan Interpersonal Skill (Solusi yang Ditawarkan Menuju Profesionalisme Guru BK). Jurnal Ilmiah Dalam Implementasi Kurikulum Bimbingan Dan Konseling, 4-6. Retrieved from http://journal2.um.ac.id/index.php/sembk/article/view/1287

Nugroho, M. S., Islam, U., Mataram, N., Program, D., Pariwisata, S., Baloq, L., ... Pariwisata, P. (2019). Sikap Masyarakat Terhadap Pengembangan Pantai Loang Baloq Sebagai Daya Tarik Wisata di Kota Mataram. Journal of Enterprise and Development, 1(2), 51-61. https://doi.org/https://doi.org/10.20414/jed.v1i02.979

Pratiwi, S. I. (2020). Pengaruh Ekstrakurikuler Pramuka Terhadap Karakter Disiplin Siswa SD. Edukatif: Jurnal Ilmu Pendidikan, 2(1), 62-70. https://doi.org/10.31004/edukatif.v2i1.90

Rahmadani, J. (2020). Penguatan Pendidikan Karakter (PPK) dalam Rencana Pelaksanaan Pembelajaran (RPP) Bahasa Indonesia Berbasis Tematik di SDN SUmbersari 2 Malang. Jurnal Penelitian, Pendidikan, Dan Pembelajaran, 15(23), 1-14. Retrieved from 
http://riset.unisma.ac.id/index.php/jp3/article/view/6986

Sappaile, B. I. (2007). Konsep Instrumen Penelitian Pendidikan. Jurnal Pendidikan Dan Kebudayaan, 13(006), 379-391. https://doi.org/https://doi.org/10.24832/jpnk.v13i66.356

Setiawati, F. A., Mardapi, D., \& Azwar, S. (2013). Penskalaan Teori Klasik Instrumen Multiple Intelligences Tipe Thurstone Dan Likert. Jurnal Penelitian Dan Evaluasi Pendidikan, 17(2), 259274. https://doi.org/10.21831/pep.v17i2.1699

Simarmata, N. N., Wardani, N. S., \& Prasetyo, T. (2019). Pengembangan Instrumen Penilaian Sikap Toleransi Dalam Pembelajaran Tematik Kelas Iv Sd. Jurnal Basicedu, 3(1), 194-199. https://doi.org/10.31004/basicedu.v3i1.122

Siregar, S. W. (2016). Assesment Dalam Bimbingan dan Konseling. 1-18.

Sobri, M., Nursaptini, N., \& Novitasari, S. (2020). Mewujudkan Kemandirian Belajar Melalui Pembelajaran Berbasis Daring Diperguruan Tinggi Pada Era Industri 4.0. Jurnal Pendidikan Glasser, 4(1), 64. https://doi.org/10.32529/glasser.v4i1.373

Sofyan. (2016). Pembelajaran Problem Based Learning dalam Implementasi Kurikulum 2013 di SMK. $\begin{array}{llll}\text { Jurnal Pendidikan } & \text { Vokasi, }\end{array}$ https://doi.org/https://doi.org/10.21831/jpv.v6i3.11275

Suhendri, H. (2011). Pengaruh Kecerdasan Matematis-Logis dan Kemandirian Belajar tehadap Hasil $\begin{array}{lllll}\text { Belajar } & \text { Matematika. } & \text { Jurnal 29-39. }\end{array}$ https://doi.org/http://dx.doi.org/10.30998/formatif.v1i1.61

Sutijan, S., Makhfud, H., Lestari, L., \& Chumdari, C. (2015). Pengembangan Instrumen Penilaian Pendidikan Karakter Terpadu. Paedagogia, 18(2). Retrieved from https://jurnal.fkip.uns.ac.id/index.php/paedagogia/article/view/7517/0

Sutrisno. (2016). Berbagai Pendekatan Dalam Pendidikan Nilai Dan Pendidikan Kewarganegaraan. Jurnal Dimensi Pendidikan Dan Pembelajaran, 4(1). https://doi.org/. http://dx.doi.org/10.24269/dpp.v4i1.56.

Suwandi, Edi, D. (2019). Analisis Tingkat Kepuasan Menggunakan Skala Likert Pada Layanan Speedy yang Bermigrasi ke Indihome. Jurnal UNTAN, 1-11. Retrieved from https://jurnal.untan.ac.id/index.php/jteuntan/article/view/31191

Wahyudin, W. (2018). Optimalisasi Peran Kepala Sekolah dalam Implementasi Kurikulum 2013. Jurnal Kependidikan, 6(2), 249-265. https://doi.org/10.24090/jk.v6i2.1932

Wijayanti, T., Sukestiyarno, \& Masrukhi. (2015). Implementasi Penilaian Kemampuan Berfikir Kritis Dan Karakter Demokratis Pada Materi Sistem Politik Indonesia Dengan Metode Pembelajaran Role Playing Berbasis Konservasi. Journal of Educational Research And Evaluation, 4(2). Retrieved from https://journal.unnes.ac.id/sju/index.php/jere/article/view/9915

Wulandari, N. P. R., Dantes, N., \& Antara, P. A. (2020). Pendekatan Pendidikan Matematika Realistik Berbasis Open Ended Terhadap Kemampuan Pemecahan Masalah Matematika Siswa. Jurnal Ilmiah Sekolah Dasar Universitas Pendidikan Ganesha, 4(2), 153-164. https://doi.org/http://dx.doi.org/10.23887/jisd.v4i2.25103

Wulandari, Sudatha, \& Simamora. (2020). Pengembangan Pembelajaran Blended Pada Mata Kuliah Ahara Yoga Semester II di IHDN Denpasar. Jurnal Edutech Undiksha, 8(1), 1-15. https://doi.org/http://dx.doi.org/10.23887/jeu.v8i1.26459

Yudhawati, D. (2020). Implementasi Penguatan Pendidikan Karakter Mahasiswa di Era Revolusi Industri 4.0 Melalui Matakuliah Pengembangan Kepribadian. Prosiding Konferensi Pendidikan Nasional, 73-77. Retrieved from https://ejurnal.mercubuanayogya.ac.id/index.php/Prosiding_KoPeN/article/view/1081

Yuliawati, L. (2018). Pengaruh Penerapan Kurikulum 2013 terhadap Tingkat Perilaku Kreatif Siswa di Lingkungan Sosial: Studi Korelasi antara Kurikulum 2013 dengan Tingkat Kreatifitas Siswa di SMAN 1 Padalarang. Bandung. 
Yusri. (2016). Pengaruh Penggunaan Media Teknologi Informasi dan Komunikasi (TIK) dengan Prestasi Belajar Bahasa Inggris Peserta Didik Kelas X di SMAN I Dekai Kabupaten Yahukimo. Ilkom Jurnal Ilmiah, 8(1), 49-56. https://doi.org/https://doi.org/10.33096/ilkom.v8i1.22.4956

Zuliani, D., Florentinus, T. S., \& Ridlo, S. (2017). Pengembangan Instrumen Penilaian Karakter pada Siswa Kelas IV Sekolah Dasar. Journal of Research and Educational Research Evaluation, 6(1). https://doi.org/https://doi.org/10.15294/jrer.v6i1.16207 